\title{
Factors Influencing Labour Turnover Intentions in Non-Governmental Organization: Insights from Christian Social Service Commission (CSSC) in Dar es Salaam
}

\author{
Y. I. Bangi and P. L. Mgeni
}

\section{ABSTRACT}

Managing labour turnover is critical for any organization sustainability and competitiveness. In the past, turnover was higher in government organizations as compared to non-Governmental Organizations. Currently however, non-Governmental organizations are facing difficulties to retain good performers, experienced and well trained employees due to high turnover. This study attempted to assess factors influencing labour turnover intentions in non-Governmental Organizations by taking the case of the Christian Social Service Commission (CSSC) in Dar es Salaam. Specifically, the study sought to assess how work-related factors, organization factors and personal factors influence labour turnover intentions at CSSC. A case study design and quantitative approach were employed in this study. Data was collected from 80 employees through standardized questionnaire, and both descriptive and inferential statistics procedures were applied in data analysis. The research revealed that organization factors and workrelated factors moderately influence turnover intentions, whereas the personal factors had no significant influence. In this respect improving on salaries, fringe benefits, personal career advancement opportunities, involvement in decision making, friendly organization policies, job securities to name a few will scale down turnover intensions. However, further studies can be carried out including more variables than those assessed in this study to reveal factors affecting labour turnover intentions.

Keywords: Labour Turnover, Non-Governmental Organization, Turnover Intentions

Published Online: February 9, 2022

ISSN: $2736-5522$

DOI: 10.24018 / ejsocial.2022.2.1.193

\section{Y. I. Bangi *}

Institute of Finance Management (IFM), Dar es Salaam, Tanzania.

(e-mail:ybangi67@gmail.com)

P. L. Mgeni

Christian Social Service

Commission(CSSC), Dar es Salaam, Tanzania.

(e-mail:pmgeni@cssc.or.tz)

*Corresponding Author

\section{INTRODUCTION}

All organizations experience a certain level of labour turnover which cause disruption especially when good performing employees leave an organization than a poor performer (Makhdoom, 2018). Despite variations that exist among organizations, non-governmental organizations are facing a serious problem of staff turnover (Lyengi, 2014). Labour turnover is not only observed from when staff leaves an organization based on organizational perspective, but also the customers' perspective. The later argues that labour turnover include transfers and promotions. Thus, this change causes an impact to those who receive services from them (Favour, 2016). Furthermore, labour turnover can either be voluntary or involuntary and both have different reasons and effects. However, this study focuses on causes of turnover rather than their types (Anvariet al., 2014).

Labour turnover is cut-across challenge in various organizations regardless of their differences. Studies show that there is a rapid growth of turnover in private sector including non-governmental organizations (NGOs) (Alias, 2018; Jayathilaka1 \& Ansar, 2021). This trend threatens the expansion of private sector which is crucial for economic growth to support the counter public sector. Research findings support that labour turnover in NGOs is more prevalent compared to public organizations (ibid). It is further leant that economic change is the leading cause of turnover in many organizations. Whenever the economy flourishes create more employment opportunities and few individuals will be hired by local companies to work for low compensation paid by some NGOs. In contrast, there some employees who will accept this low payment and may not leave their organizations (URT, 2017). Given the current improvement of the economy and organizations increase of salaries in the private sector the staff turnover is a particularly important. Yet, wages are only one of the variables that affect turnover.

Like any other organizations, the CSSC organization has been facing rapid staff turnover rate since the 
year 2015. Its operations have grown significantly since 2016 and they require competent and professional employees who can support the organization in executing day-to-day strategic objectives and goals. Information obtained from the Human Resource Department of CSSC revealed that labour turnover rate increased to $16.0 \%$ in 2015 to $28.0 \%$ in 2018 .

Although several initiatives were taken by CSSC to improve staff working environment, still the problem of staff turnover persisted (Marwa, 2016). The critical question to be answered by this study was what determines labour turnover in non-governmental organization specifically at CSSC. To answer this question, the study is set to identifying the factors influencing labour turnover in non-governmental organizations.

The surveyed literatures show that many studies conducted on labour turnover focused in organizations such insurance companies (Ryu \& Jinnai, 2020; Wells \& Peachey, 2014) and some were done in other organizations such as financial institutions (Favour, 2016) and Higher learning Institutions (Long et al., 2012). Some tracer studies that focused on labour turnover in non-governmental organizations (Uddin, 2019; Zhang, 2016; Marwa, 2016) focused secular non-governmental organizations and not on faith based ones such as CSSC.

Employees' retention is not only saving money but also hold talented individuals crucial for the organization performance. Conversely, employee turnover causes negative impacts such as work overload, burnout, and dissatisfaction, and compromised of customer care. Moreover, Employees' satisfaction and customer satisfactions are inseparable and cannot be underestimated (Subramony\&Holtom, 2011). In this regard, reducing the turnover rates could reduce cost in terms of hiring new ones and retaining customers and eventually maintain financial performance (Amina, 2014). Thus, this study attempted to bridge this gap via assessing those factors that influence labour turnover intentions in the context of Tanzania, specifically in non-governmental organizations. Despite various efforts attempted by CSSC to address this problem, but still persists. In this base, the paper aimed at assessing factors influencing labour turnover intentions in non-governmental organizations. Specifically, the study focused on assessing the influence of work-related factors, organization factors and personal factors at CSSC in Dar es Salaam.

\section{PROCEDURE FOR PAPER SUBMISSION}

Labour turnover is a common practice in all organizations which can either be voluntary or involuntary. Generally, it refers to the rate at which employees leave an organization. In most cases it can be costly and damaging. In a broader sense it encompasses all organization leavers through promotions, demotions, new employment, resignations, retirement or retrenchment as result or redundance. All these types may call for replacement to ensure organization continuity (Armstrong, 2009). Though turnover is a challenge of all organizations, it is learnt from literatures that turnover intentions are higher in areas where there is low unemployment since employees have an alternative of moving from one job to another. Among other factors inappropriate systems of motivation, over workload, office polices, promotions and work performances mainly influence voluntary turnover (Rizwan, 2014).

Non-governmental organizations are independently groups that co-exist and operate along with government organization. NGOs sometimes are named as civil societies and organized at different levels such as community, national and international. However, the main goal is to serve the society economically, politically and socially (Omofonmwan, 2009). These are among the private sector organizations which are faced with high turnover intentions due continuous increase in unemployment. In such situations, organization policies favor the employer at the expense of the employees. Hence, causing dissatisfactions among them and accelerated turnover (Latif \&Saraih, 2016).

Herzberg (1959), Two-Factor theory and Expectancy theories guide the current study due to their relevance as they focus on staff motivation and how it aligns to retention that eventually addresses staff turnover. The Two-Factor theory argues that the employees are attracted by both intrinsic and extrinsic motivations. Intrinsic are internal which include recognition, the work itself, responsibility, advancement, achievement, and growth. Conversely, extrinsic variables induce motivation from outside such as salary, work environment, company policies, industrial relation and supervisory or management styles (Armstrong, 2019). Both satisfier and dissatisfier factors are important for the turnover to occur or not to occur. They also guide researchers to assess factors influencing staff turnover in both government and non-Governmental organizations (Dasilveira, 2020).

On the other hand, expectancy theory by Vroom (1964) contends that behavior is motivated by projected consequences. The theory further contends that change of individual behavior in a particular way is based on the desired outcome. This theory relates with the current study because if employees expect to receive high salary, good work environment, achievement or expected to be treated fairly they will be satisfied and their turnover intention will be low when these expectations are met, and the vice versa will also be true. 
There are multiple causes to labour turnover intentions and varies from one organization to another. It is essential to the organization management to identify relevant signals and take appropriate measures. Nzobanaliba (2019) advocated that absenteeism, frequent late coming can connote turnover since they represent signs of withdrawal from work. Attitudinal behavior plus other organizational factors may influence turnover. Chandra and Anjaiah (2019) added that co-workers' intentions are also significant on others to leave the organization. It is learnt that, the more positive intentions of co-works to leave, found to have a strong impact to other employees to quit as well. When dissatisfied works leave an organization, they are likely to converse their peers to leave. However, most people vacate from organizations fueled by economic factor reasons which can be used to envisage labour turnover in the market. Large organizations have been able to scale down labour turnover through provision of advancement chances and high wages to safeguard employee retention (Kilonzo, 2018). On the same line, Mustafa (2016) disclose that stressors cause employees' turnover. This can be due to mismatch between what is expected and how to meet such expectations.

Organization politics are inevitable and they are found in all organizations regardless of their differences. They involve tactics of executing power and authority in realizing desired goals. Despite the positive impacts resulting from political games, they also cause negative impacts such as; conflicts, unethical practices, loss of reputation and turnover acceleration in organizations (Hussain \&Xian, 2019). Certain political behaviors favor those who engage and accepted by the authority and negatively affect none players of organization politics, hence lead to turnover intentions.

Working environment is argued to have insignificant impact on high turnover compared to other factors (Mensah, 2014). Employees are likely stay when the working environment is conducive and vice versa. It is further learnt that high level of organization inefficiency was associated with high employee turnover as most of them tend to leave for greener pasture and stable employment. Thus, unstable organization is indicated by high inefficiency employees leave for an alternative stable and better organization.

Another comparative study by Pillay (2011) and supported by Ndamo (2019), discovered that job security, career opportunities, work environment and workplace organization are highly valued factors by employees in public sector, whereas employees in a private sector rated job security, professional practice and workplace organization as priority for them to stay in an organization. Indeed, an organization working conditions is a decisive factor for employees to stay or quit. Therefore, it should be understood that conducive working conditions may motivate employees to be retained in an organization.

Moreover, Mendis (2017) revealed that career commitment strongly predicts employees' turnover intentions. Employees are highly committed to their organization are less likely to leave. This was learnt to those with individuals with high commitment. Kahiro (2015) commended that development of an employee lowers turnover in an organization. Further, the study found that based on career development, employees advance through various stages of career progress. It is anticipated that the process of career development will be through formal training.

The major focus on staff turnover studies have concentrated on general identification of turnover factors and not categorically such as work-related factors, organizational factors or personal factors. It is also revealed that tracer studies have been conducted in non-governmental organization where most employees are hired. As such, the paper sought to bridge the revealed gap and provide implementable comments for remedy.

\section{A. Conceptual Framework}

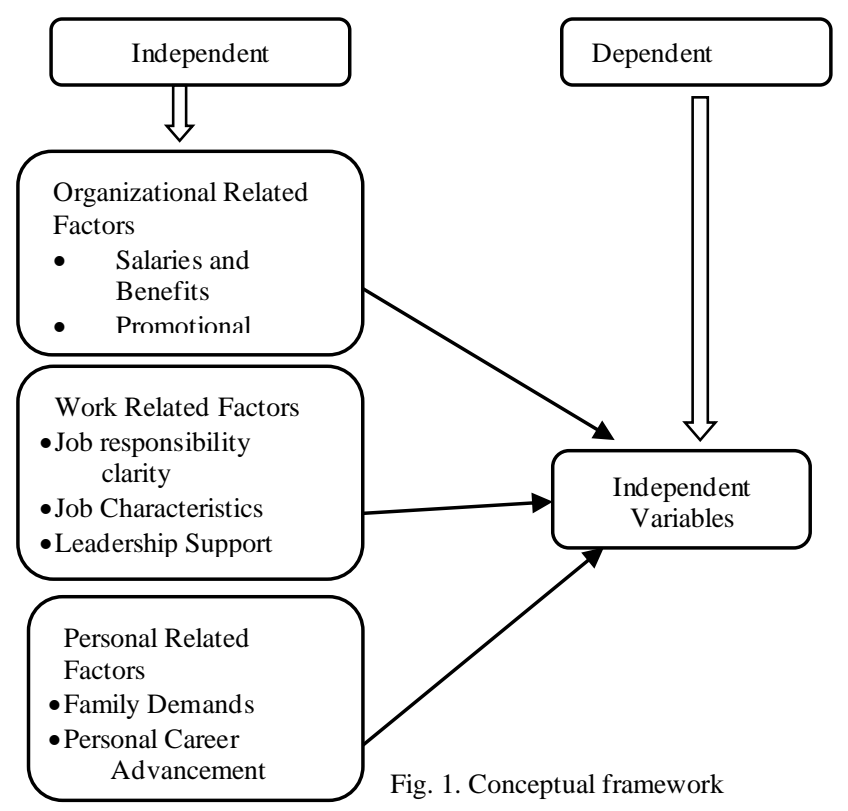


The essence of a conceptual framework is to show how independent and dependent variables relate. In this study independent variables include work related factors, organizational factors and personal factors, whereas the dependent variable is employee turnover. It is inversaged to be a cause and effect relationship where independent variables will be regressor and turnover will be regresant. The decision of employees to leave will depend on the independent variable status. Whenever, independent variables are positively perceived then turnover intensions will be reduced and vice versa. The number of components for each category can vary from one organization to another. Fig. 1 above represents the relationship.

\section{ReseARCH Methodology}

This study employed case study design and quantitative research approach with stronger emphasis on quantitative method since all variables were measurable through statistical procedures. The target population included all employees at CSSC where structured questionnaire was distributed to 110 respondents and 80(73\%) were filled and returned. Documentary review was also employed in data collection from a purposively selected interviewee. In assessing the selected variables, this paper adapted instruments from surveyed literatures. Specifically, the paper adapted one variable and regression approach from Anvariet al. (2014) to measure the perceive turnover intensions. SPSS version 21 computer software was employed analyze to determine correlation between variables and hypothesis testing through regression analysis. Internal consistency reliability through Cronbach alpha $(\alpha)$ which was found to be 0.72 where the acceptable range is $(0.70 \leq \alpha)$ as suggested level by Hair et al. (1998). In addition, Kaiser-Meyer-Olkin (KMO) also tested the sampling adequacy of the study and found to be acceptable as well with analysis variables of 0.863 , and the cut-off range is $(0.70 \leq \alpha)$. In testing the hypothesis, this paper adapted a multivariate analysis of statistical analysis where multiple regressions were performed.

\section{A. Linear Regression Model}

Multiple linear regressions (MLR) aimed at modeling the relationship between independent and dependent variables, which in the current in the current study, job related factors, Organizational factors and personal determining factors influencing employee turnover.

$$
\gamma=\alpha+\beta_{1} \text { jobrelatedfators }+\boldsymbol{\beta}_{2} \text { Organizationalfactors }+\boldsymbol{\beta}_{3} \text { personalfactors }+\varepsilon
$$

Where: $\mathrm{Y}=$ Labour turnover, $\boldsymbol{\alpha}=\mathrm{Y}$ intercept, $\boldsymbol{\beta}_{1}, \boldsymbol{\beta}_{2}$, and $\boldsymbol{\beta}_{3}=$ coefficients of variables, $\mathrm{X} 1=$ job related factors, $\mathrm{X} 2=$ organization factors, $\mathrm{X} 3=$ Personal factors and $\varepsilon=$ Error term

\section{RESEARCH FINDINGS}

\section{A. Basic Information of the study sample}

The study involved a sample of $80(73 \%)$ respondents working in various departments who filled the self-administered questionnaires. We observed that; $\mathrm{n}=38 ; 47.5 \%$ of total respondents were male and $\mathrm{n}=42 ; 52.5 \%$ were female. Furthermore, results indicate that $\mathrm{n}=4 ; 5.0 \%$ respondents were aging between $18-25$ years, $n=27 ; 33.8 \%$ of the respondents were aging between $26-35$ years, $n=35 ; 43.8 \%$ were aging between 36 and 45 . Also, $n=12 ; 15.0 \%$ aged between 46-55, and the remaining $n=22 ; 5 \%$ were above 55 years. The statistics signify that all age groups were considered in data collection. However, more than $50 \%$ comprised of the age between 36 to 45 years. This connotes that the age between $36-45$ years comprised of an active man power available in the labour market which is also prone to turnover intentions since they still have more time to sale their labour compared to more aged employees. The study statistics also indicated that $n=26 ; 32.5 \%$ worked with the current organization for the period of 1-2 years, $n=39 ; 48.8 \%$ worked between $3-4$ years with their current organization. $n=15 ; 18.8 \%$ worked with their employer for five years and above. Therefore, these statistics show that most of the respondents were new to their employer.

\section{B. Multicollinearity}

Multicollinearity test revealed that the independent variables were not highly correlated with $\mathrm{r}=0.401$ which is acceptable $(\mathrm{r} \leq 0.9)$ (Pallant, 2005). As such, all independent variables were included in the modeling procedure using an ordered logistic model. 
European Journal of Humanities and Social Sciences www.ej-social.org

TABLE I: MULTICOLLINEARITY TEST

\begin{tabular}{llll}
\hline \hline Factors & & & \\
\hline \multirow{2}{*}{ 1. Organization factors } & $\mathrm{R}$ & & \\
& Sig. & & \\
2. Work related factors & $\mathrm{R}$ & $0.336^{* *}$ & \\
& Sig. & 0.000 & \\
\multirow{3}{*}{ 3. Personal Factors } & $\mathrm{R}$ & $0.302^{* *}$ & $0.401^{* *}$ \\
& Sig. & 0.000 & 0.000 \\
\hline \hline
\end{tabular}

\section{C. $\quad$ Normality Test and Outliers of the Factors}

The obtained Skewness values of factors in this study ranged between -0.285 and 0.995 and kurtosis values ranged between -1.597 and 0.225 . The factors of the study were therefore univariate normal as all the skewness values obtained were less than 3 or greater than -3 and all obtained kurtosis values were less than 10 (Kline, 2015). Regarding multivariate normality assessed, the obtained kurtosis critical ratios (cr) ranged between -1.7637 and 0.770548 . The three factors were therefore multivariate normal as all the $\mathrm{cr}$ values were less than 1.96 and greater than -1.96 .

TABLE II: NORMALITY OF THE FACTORS

\begin{tabular}{cccccccccccc}
\hline \hline & $\mathrm{N}$ & Minimum Maximum & Mean & $\begin{array}{c}\text { Std. } \\
\text { Deviation }\end{array}$ & Skewness & \multicolumn{2}{c}{ Kurtosis } & $\begin{array}{c}\text { Kurtosis critical } \\
\text { ratio (c.r) }\end{array}$ \\
\cline { 2 - 11 } Descriptive Statistics & Statistic Statistic & Statistic & Statistic & Statistic Statistic & $\begin{array}{c}\text { Std. } \\
\text { Error }\end{array}$ & Statistic & $\begin{array}{c}\text { Std. } \\
\text { Error }\end{array}$ & \\
\hline $\begin{array}{c}\text { Personal related } \\
\text { factors }\end{array}$ & 80 & 30 & 60 & 45.98 & 7.257 & -0.031 & 0.146 & -0.515 & 0.292 & -1.7637 \\
$\begin{array}{c}\text { Work Related Factors } \\
\text { Organization Factors }\end{array}$ & 80 & 5.00 & 27.00 & 12.0072 & 7.08284 & 0.995 & 0.146 & -0.335 & 0.292 & -1.14726 \\
Valid N (list wise) 80 & 277 & 1 & 4 & 2.80 & 0.714 & -0.285 & 0.146 & 0.018 & 0.292 & 0.061644 \\
\hline \hline
\end{tabular}

\section{Regression Output}

The analysis through Multiple regression was performed to examine the three suggested hypotheses. The analysis output in Table III below shows all the three factors namely; Organizational factors, work related factors and personal factors are positively related to turnover intentions at CSSC by $(\beta=0.20$; $\operatorname{sig}=0.032),(\beta=0.298 ; \operatorname{sig}=0.033)$ and $(\beta=0.188 ; \operatorname{sig}=0.123)$ at a recommended $p$-value of $0.05(5 \%)$ significant value. We further revealed that organizational factors (ORG) and work-related factors (WRF) are statistically significant on turnover intentions whereas; personal related factors (PEF) are statistically insignificant since it is above the recommended $p$-value of 0.05 . we also noted that the influence of selected variables on turnover intentions is less than $50 \%$ ( $\mathrm{ORG}=20 \%, \mathrm{WRF}=29.8 \%$ and $\mathrm{PEF}=18.8 \%$ ). Thus, impact of this factors is very low whereby other factors not included in this study impacts more. As such, the CSSC need to investigate more factors leading to turnover intentions of its employees while paying attention to significant factors.

TABLE III: REGRESSION COEFFICIENTS ON THE INFLUENCE OF EACH FACTOR ON TURNOVER

\begin{tabular}{|c|c|c|c|c|c|c|}
\hline & \multirow[t]{2}{*}{ Model } & \multicolumn{2}{|c|}{$\begin{array}{c}\text { Unstandardized } \\
\text { Coefficients }\end{array}$} & \multirow{2}{*}{$\begin{array}{c}\begin{array}{c}\text { Standardized } \\
\text { Coefficients }\end{array} \\
\text { Beta } \\
\end{array}$} & \multirow[t]{2}{*}{$\mathrm{t}$} & \multirow[t]{2}{*}{ Sig. } \\
\hline & & $\mathrm{B}$ & Std. Error & & & \\
\hline \multirow{4}{*}{1} & (Constant) & 23.055 & 3.527 & & 6.538 & 0.000 \\
\hline & ORG & 0.203 & 0.107 & 0.241 & 1.895 & 0.032 \\
\hline & WRF & 0.298 & 0.135 & 0.278 & 2.205 & 0.033 \\
\hline & PEF & 0.188 & 0.120 & 0.195 & 1.565 & 0.123 \\
\hline
\end{tabular}

a. Dependent Variable: Turnover

TABLE IV: SUMMARY OF HYPOTHESES

\begin{tabular}{|c|c|c|c|}
\hline Hypothesis & Relationship & Sig & Results \\
\hline $\mathrm{H} 1$ & $\begin{array}{l}\text { Organization factors positively influences turnover } \\
\text { intention }\end{array}$ & 0.032 & $\begin{array}{l}\text { Null hypothesis } \\
\text { Accepted }\end{array}$ \\
\hline $\mathrm{H} 2$ & $\begin{array}{l}\text { Work related factors positively influences turnover } \\
\text { intention }\end{array}$ & 0.033 & $\begin{array}{l}\text { Null hypothesis } \\
\text { Accepted }\end{array}$ \\
\hline $\mathrm{H} 3$ & $\begin{array}{c}\text { Personal factors positively influences turnover } \\
\text { intention }\end{array}$ & 0.123 & $\begin{array}{l}\text { Null hypothesis } \\
\text { Rejected }\end{array}$ \\
\hline
\end{tabular}


The findings of this study are similar to those of Eatough (2010) and (Batt, 2011). In their studies work-related behavior, management style, limited resources availability, incorrect job instructions/job descriptions, autonomy, team collaboration, training, fairness and leadership styles were revealed to be the causes of turnover intentions. Though they are not categorized into groups like in the current study still they portray similar factors for turnover intentions. Regarding leadership styles it is among the reasons why individuals decide to leave or stay in a company (Batt, 2011). More emphasis is added that leadership styles significantly impact on turnover intentions and causes significant impact (Donkor, 2021).

Based on findings from regression analysis the positive and significant influence of organization factors imply that factors such as salaries and benefits, promotional changes, organizational policies and job security have strong influence on turnover intentions. As such, salary review, provision of promotional opportunities, enhancement of job security and supportive policies enhance retention and lower turnover intentions. How we structure compensation, promotional changes and policies are essential to employees' satisfaction. Fair compensation based on their productivity and sense of equal value to all employees need to be emphasized.

However, the study found no significant influence of personal factors on labour turnover intention. To be more specific, personal factors like family demands, personal career and advancement and work life balance had positive and insignificant influence on turnover. This implies that factors relate to turnover intentions have no effect. Despite this, organizations need create an environment which may not accelerate the personal factors to influence turnover. This is possible by ensuring life balance by not overworking employees, frequent salary review to link with actual living costs from time to time and supporting employee's career development.

\section{CONCLUSION AND RECOMMENDATIONS}

This study aimed at assessing factors influencing labour turnover intensions at CSSC. Specifically, the paper focuses on work related factors, organizational factors, and personal factors. The study concludes that organizational factors and work-related factors have moderate positive influence on turnover intentions, while personal factors have no influence at CSSC. These findings imply that more efforts need to be directed to salary, promotion opportunities, training and development, leadership styles, organizational policies and job security. Salary review from time to time is highly recommended. Also, having policies which support career advancement to scale down turnover intensions. However, moderate positive influence of both organizational and work-related factors implies that there are other factors that impact labour turnover at CSSC. As such, it is further recommended that more studies including other variables than those identified may be conducted and might reveal different and essential findings.

\section{CONFLICT OF INTEREST}

Authors declare that they do not have any conflict of interest.

\section{REFERENCES}

Alias, N. E., Rohmanan, N. H., Koe, S. I. W. Othman, R. (2018). "Factors Influencing Turnover Intention in a Malaysian Manufacturing Company" "Factors Influencing Turnover Intention in a Malaysian Manufacturing Company" in International Conference on Economics, Business and Economic Education, KnE Social Sciences, pages 771-787. DOI 10.18502/kss.v3i10.3171

Anvari, R, Z. JianFu\&Chermahini, S. H. (2014). Effective Strategy for Solving Voluntary Turnover Problem among Employees. Roya Anvari et al. / Procedia - Social and Behavioral Sciences, 129, 186-190.

Armstrong, M., \& Taylor, S. (2017). Armstrong handbook of human resource management practice (13 ${ }^{\text {th }}$ ed.). London: Kogan Page. Batt, R. (2011). An Employment Systems Approach to Turnover: Human Resources Practices, Quits, Dismissals, and Performance. Academy of Management Journal, 54(4), 695-717. https://www.jstor.org/stable/23045107

Chandra, S. F. \& Anjaiah, P. (2019). The impact of coworker support and organizational embeddedness on turnover intention among restaurant employees, Journal of Human Resources in Hospitality \& Tourism, 18(3), 394423. DOI: $10.1080 / 15332845.2019 .1599789$

Dasilveira, I. , Yang, J., Mensah, I. \&Quarcoo, A. (2020). Human Resource Management Practices and Employee Turnover Intentions Nexus: Does the Mediating Role of Job Satisfaction Matter? Open Journal of Business and Management, 8, 1-29. doi: $10.4236 /$ ojbm.2020.81001.

Donkor, F., Appienti, W.A. \&Achiaah, E. (2021). The Impact of Transformational Leadership Style on Employee Turnover Intention in State-Owned Enterprises in Ghana. The Mediating Role of Organizational Commitment. Public Organization. https://doi.org/10.1007/s11115-021-00509-5

Eatough, E. M. (2010). Factors That Influence the Turnover Intentions of Employees in the Tourism Sector in Zimbabwe. International Journal of Management and Business Research, 5(12), 2226-8235. 
European Journal of Humanities and Social Sciences

www.ej-social.org

Favour, D. (2016). An Investigation into the Impact of Leadership Styles on Employee Retention: Identifying which Leadership Style best encourages Employee Retention in the Nigerian Banking Sector [Unpublished Theisis]. College of Ireland.

Hair, J. F., Anderson, R. E., Tatham, R. L., \& Black, W. C. (1998). Multivariate data analysis (5th ed.). Upper Saddle River, New Jersey: Prentice Hall.

Herzberg, F. (1959). The motivation to work. New York: Wiley.

Hussain, S., \&Huei Xian, S. (2019). Factors Affecting Employees' Turnover Intention in Construction Companies in Klang, Selangor. KnE Social Sciences, 3(22), 108-131. https://doi.org/10.18502/kss.v3i22.50

Jayathilaka, A., \& Ansari, M. (2021). Impact of NGO Governing Issues for the Employee Turnover Intention (A Study Based on Sri Lanka). Journal of Research in Humanities and Social Science, 9(8), 28-32. www.questjournals.org

Kahiro, F.M. (2015). Influencing labour turnover in Commercial Banks: Case Study NBC Bank in Kenya [Unpublished Thesis]. Open University of Tanzania.

Kilonzo J.M. (2018). Effects of Human Resources Policies on Turnover Level within the Banking Sector in Kenya. A case study of Barclays Bank Kenya Queensway Branch [Unpublished Research]. Management University of Africa

Kline, R. B. (2015). Principles and practice of structural equation modeling. Guilford publications.

Latif, F.D.A \&Saraih, U.N. (2016). Factors Influencing Employee Turnover in Private Sector: A Concept Paper. Australian Journal of Basic and Applied Sciences, 10(7), 51-55.

Makhdoom, T. R. (2018). Employees' exit from manufacturing organizations: Investigating the consequences. Pakistan Administrative Review, 2(2), 243-252. https://nbn-resolving.org/urn:nbn:de:0168-ssoar-58645-1

Marwa C.M. (2016). Analysis of Factors leading to teachers Mobility in Rural District Councils. A case of Simanjiro District Council in Tanzania [Unpublished Master's thesis]. Mzumbe University Tanzania

Mendis M. (2017). The Impact of Reward System on Employee Turnover Intention in Logistics Industry in Sri lanka. International Journal of Scientific \& Technology Research, 6(9).

Mensah R.D. (2014). Effects of Human Resource Management Practices on Retention of Employees in the Banking Industry in Accra, Ghana [Unpublished Research Paper]. Kenyatta University, Kenya

Mustafa K. (2016). The Impact of Employee Training and Innovation on Turnover Intention: An Empirical Research. International Journal of Academic Research in Business and Social Sciences, 6(1).

Ndamo, M. P. (2019). Causes and Effects of Labour Turnover on the Performance of Local Government Authorities in Tanzania: A Case of Iramba District Council [Unpublished Master's thesis]. The Open University of Tanzania.

Nzobanaliba, F. (2019). The impact of Employees Turnover on Organization Performance a case of the Office of Attorney General. [Unpublished Research]. University of Dar es Salaam.

Omofonmwan, S.I. \& Odia, L.O. (2009). The Role of Non-Governmental Organisations in Community Development: Focus on Edo State-Nigeria. The Anthropologist, 11:4, 247-254. DOI: 10.1080/09720073.2009.11891111

Pallant, J. (2015). SPSS Survival Manual: A step by step guide to data analysis using SPSS for Windows (Version 12). Crow's Nest, NSW: Allen \& Unwin.

Pillay, S. (2011). Employee retention: A multiple case study of South African national government departments. [Unpublished doctoral thesis]. Durban University of Technology.

Rizwan, M., Arshad, M. Q., Munir, H. M. A., Iqbal, F., \& Hussain, A. (2014). Determinants of Employees intention to leave: A Study from Pakistan. International Journal of Human Resource Studies, 4(3), 1-19. https://doi.org/10.5296/

Ryu,S., \& Jinnai, Y. (2020). Effects of Monetary Incentives on Teachers Turnover. A longitudinal Analysis. Public Personnel Management Journal, 5(2),13-19.

Subramony, M., \&Holtom, B. C., (2011). Customer Satisfaction as a Mediator of the Turnover- Performance Relationship. Journal of Organizational Psychology, 11(1).

Uddin, M., Paul, R., Khan, T. \& Ali, S. (2019). Exploring the Factors Affecting Employee's Satisfaction in Non-Government Organizations (NGOs) of Bangladesh: An Experience from Bangladesh Rural Advancement Committee (BRAC). Open Journal of Social Sciences, 7, 1-23.doi: 10.4236/jss.2019.78001.

URT. (2012). Assessment of the Social Welfare Workforce in Tanzania, Ministry of labour, Employment and Youth Development. Annual Report.

Vroom, V. (1964). Work and Motivation. Wiley and Sons, New York.

Wells, J., \& Peachey, K. (2014). Examining the influence of transformational leadership, organization commitment, job embeddings, job search behavior on turnover intentions in intercollegiate athletics. Leadership and Organization Development Journal, 35(8), 740-755.

Zhang, Y. (2016). A Review of Employee Turnover Influence Factor and Countermeasure. Journal of Human Resource and Sustainability Studies, 4(2), 85-91. https://doi.org/10.4236/ihrss.2016.42010

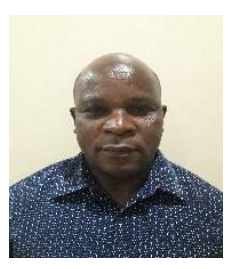

Yustin Ignas Bangi was born on 01 January 1967 in Iringa, Tanzania. He graduated from the University of Dar es Salaam, Tanzania with a Bachelor's degree in Education in 2002. In 2008, he graduated from the same University of Dar es Salaam, in Masters degree in Education Management and Administration. He received his Ph.D. degree in Management in 2016 from the Faculty of Management at Mohanlal Sukhadia University: Udaipur, India. He has more than 20 years experience as a tutor and lecturer in teachers training colleges and higher learning instittionsnn respectively. He started tutoring in Teachers' colleges from 1992 to 2005 before joining Dar es Salaam University College of Education in 2006 to April 2008. From May 2008 to date, he is a lecturer at the Institute of Finance Management (IFM), in Dar es Salaam, Tanzania in the areas of Strategic Management, Principles of Management, Performance and Compansations and Organizational Bahaviour, to both undergraduates and postgraduate. He has wide research experience in education management and general management. He has been engaging in trainings to various organizations in customer service and performance, Leadership Skills, Negotiation Skills to name a few, at all levels. He published more than 10 manuscripts, of which $70 \%$ have been published in international journals.

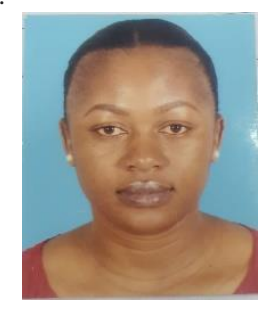

Prisca Levi Mgeni was born on 11 October 1984 in Mbeya, Tanzania. He has a Bachelor's degree in Law (LLB) from Tumaini University, Dar es Salaam (2008); holder of Post graduate Diploma in Business Administration from the Institute of Finance Management (IFM) and holds a Masters degree in Human Resource Management (MSC. HRM) from the Faculty of Economics and Management Science, Department of Managem, Institute of Finance Management (2021). She worked with Care International Tabora and Dar es Salaam, Tanzania from 2012 to 2015. Currently, she is an employee of the Christian Social Service Council (CSSC) as Human Resource and Administrative Manager since 2016. 